\title{
Yield and Nutrient Uptake of Common Bean Cultivars as Affected by Plant Population and Growing Season
}

\author{
Luiz Antônio Zanão Júnior ${ }^{1}$, Anderson Rosa ${ }^{2}$, Natalia Pereira ${ }^{3}$, Rafael Bissolli Pescador ${ }^{4}$ \\ \& Edna Aparecida de Andrade ${ }^{2}$ \\ ${ }^{1}$ Agronomic Institute of Paraná, Santa Tereza do Oeste, Paraná, Brazil \\ ${ }^{2}$ Department of Energy Engeneering in Agriculture, University of Western Paraná, Cascavel, Paraná, Brazil \\ ${ }^{3}$ Department of Agricultural Engeneering, University of Western Paraná, Cascavel, Paraná, Brazil \\ ${ }^{4}$ Department of Agronomy, University Center FAG, Cascavel, Paraná, Brazil \\ Correspondence: Natalia Pereira, Department of Agricultural Engeneering, University of Western Paraná, \\ Cascavel, Universitária St, 2069, 85819-110, Paraná, Brazil. Tel: 55-45-3220-3000. E-mail: \\ pe.nataliaa@gmail.com
}

Received: June 25, 2018

Accepted: July 26, $2018 \quad$ Online Published: September 15, 2018

doi:10.5539/jas.v10n10p308

URL: https://doi.org/10.5539/jas.v10n10p308

\begin{abstract}
Brazil's production of common bean is insufficient to supply the domestic market. Factors such as plant density, cultivar, growing season, and nutrient uptake affect bean yield, suggesting the need for more studies to optimize bean production. The objective of this work was to evaluate the effect of plant density on seed yield components and nutrient uptake of two common bean cultivars grown in two different seasons. Field experiments were carried out at the IAPAR experimental site in Santa Tereza do Oeste, Paraná, Brazil in the wet and dry season using five planting densities: $6,8,10,12$, and 14 plants $\mathrm{m}^{-1}$. The experimental design was randomized blocks with four replications and two bean cultivars of different growth types. The cultivars used were 'IPR Curió' (type I) and 'IPR Tangará' (type II), both have erect plant architecture and belong to the Carioca group. Obtained data underwent analysis of variance and regression. Macronutrient uptake was not affected by crop density probably due to nutrient availability and compensatory growth of the crop. High crop density per linear meter decreased the number of seeds and pods per plant but did not affect the first pod height or yield in both cultivars and seasons.
\end{abstract}

Keywords: Phaseolus vulgaris L., yield components, plant population

\section{Introduction}

Common bean (Phaseolus vulgaris L.) has great socio-economic importance in tropical countries because its seeds are a staple in this population's diet and an excellent source of protein and iron. In Brazil, it is grown in all regions employing low- and high-tech cropping systems (Lima et al., 2016). However, Brazil's bean production is insufficient to supply the domestic market mainly due to low yields, on average $1 \mathrm{t} \mathrm{ha}^{-1}$ (CONAB, 2017). To this end, field studies are needed to optimize crop management practices in order to boost yields.

Crop density in different growing seasons is important because it can influence crop microclimate and consequently the yield. The ideal crop density leads to the most efficient utilization of growth factors and the maximum yield. According to Bezerra et al. (2010), the density and arrangement of plants determine the degree of interplant competition and the stage at which it is the most intense, directly reflecting on seed yield. Intense competition at early stages of plant development may lead to the emergence of unproductive plants and a higher incidence of diseases (Vieira et al., 2010).

Additionally, crop density in bean affects water and fertilizer use efficiency, seed cost, and crop management practices. The optimum plant population differs with the availability of soil moisture and nutrients; thus, plant density directly or indirectly affects the production potential of common bean cultivars (Masa et al., 2017).

Knowing the variations of plant population affect total bean yield (Morgade \& Willey, 2003) augment the yield of common beans requires an analysis of the current used density in the direction of determination of a population that could produce the highest seed yield and solve problems of fertilization. Very limited work has been done on its agronomic management and varietals improvement in spite of relevance of the crop (Tuarira \& Moses, 2014). 
As reported by Soratto et al. (2017) nutrient uptake may increase seed yield, mainly at lower plant densities. The common bean usually has a great capacity for compensation, that is to occupy empty areas where the number of established plants is lower than the recommended (J. G. Silva \& C. C. Silva, 2005). However, this compensation may be higher or lower depending on the cultivar's growth characteristics. Bush-type cultivars and those with determinate growth branch less and therefore compensate less (Comissão Técnica Sul-Brasileira de Feijão, 2012).

Crop density, cultivar, growing season, and nutrient uptake affect bean yield. Therefore, the objective of this work was to evaluate the effect of planting density on seed yield components and nutrient uptake of two bean cultivars grown in the wet and dry season.

\section{Material and Method}

\subsection{Location Characterization}

This work was carried out at the experimental site of the Agronomic Institute of Paraná, Santa Tereza do Oeste, Paraná, Brazil. According to the Köppen classification, climate in the experimental area is of the Cfa type with the following characteristics: subtropical, humid, the annual average temperature is below $18{ }^{\circ} \mathrm{C}$ and the average temperature in the warmest month above $22^{\circ} \mathrm{C}$, hot summers, not very frequent frosts, and precipitation mostly concentrated in the summer months but without a clearly defined dry season.

The soil on the site was classified as Typic Dystroferric Red Latosol (Santos et al., 2014a) equivalent to the Rhodic Hapludox of the USDA soil classification (Soil Survey Staff, 2010) of clayey texture. Soil chemical and physical analyses were carried out before sowing, and the results were: clay $=580 \mathrm{~g} \mathrm{~kg}^{-1} ; \mathrm{pHCaCl}_{2}=5.00$; carbon $=35.8 \mathrm{~g}$ $\mathrm{dm}^{-3} ; \mathrm{P}=11.8 \mathrm{mg} \mathrm{dm}^{-3} ; \mathrm{K}=291.0 \mathrm{mg} \mathrm{dm}{ }^{-3} ; \mathrm{Ca}=8.50 \mathrm{cmol}_{\mathrm{c}} \mathrm{dm}^{-3} ; \mathrm{Mg}=2.50 \mathrm{cmol}_{\mathrm{c}} \mathrm{dm}^{-3} ; \mathrm{Al}=0.0 \mathrm{cmol}_{\mathrm{c}} \mathrm{dm}^{-3}$, and base saturation $64 \%$.

\subsection{Experimental Design and Analytical Procedures}

The experiment was conducted during two different growing seasons known as wet- and dry-season harvest, common for crop production in the region. For the wet season, sowing was carried out in October 2014 and for the dry season in February 2015.

Treatments encompassed five planting densities: $6,8,10,12$, and 14 plants $\mathrm{m}^{-1}$. The experimental design was randomized blocks with four replications each and two bean cultivars of different growth types in each season. Growth type I (determinate, bush, and erect) and type II (indeterminate, bush, erect, with few branches) cultivars were used (Vieira et al., 2005). The cultivars were 'IPR Curió' (type I) and 'IPR Tangará' (type II), both from the Carioca group. 'IPR Curió' has a growth cycle of 70 days and 'IPR Tangará' 87 days.

No-till cultivation system was used. Each experimental plot had six rows five meters long spaced $0.45 \mathrm{~m}$ apart. Four central rows in each plot were considered in this experiment, and two guard rows on both sides and two meters from both ends were discarded.

The following fertilization scheme was used at planting: $20 \mathrm{~kg} \mathrm{ha}^{-1} \mathrm{~N}, 60 \mathrm{~kg} \mathrm{ha}^{-1} \mathrm{P}_{2} \mathrm{O}_{5}$, and $60 \mathrm{~kg} \mathrm{ha}^{-1} \mathrm{~K}_{2} \mathrm{O}$. Crop treatments were carried out following technical recommendations for the cultivars used. Nitrogen top-dressing fertilization was carried out at the $\mathrm{V}_{3}$ stage using $100 \mathrm{~kg} \mathrm{ha}^{-1}$ of urea $(45 \% \mathrm{~N})$.

The following traits were evaluated: first pod height, number of pods per plant, number of seeds per plant, yield, and foliar levels of macronutrients.

At harvest, 10 plants were randomly collected to determine the number of pods per plant, number of seeds per pod, and first pod height measured from the soil surface.

Plots were harvested mechanically. The yield was determined in $\mathrm{kg} \mathrm{ha}^{-1}$ adjusted to $13 \%$ humidity.

At full flowering, samples of mature leaves were collected from the apex of thirty plants in each plot, according to Oliveira (2004). The samples were then washed with distilled water and dried in a forced air circulation oven at $65^{\circ} \mathrm{C}$ for $72 \mathrm{~h}$. Next, the samples were milled in a Wiley-type mill with a $0.84 \mathrm{~mm}$ mesh sieve. Dry matter was mineralized using the nitric-perchloric mixture $\left(3: 1 \mathrm{v} \mathrm{v}^{-1}\right)$. Concentrations of $\mathrm{Ca}$ and $\mathrm{Mg}$ were determined by atomic absorption spectrophotometry, $\mathrm{K}$ by flame emission photometry, $\mathrm{S}$ by turbidimetry, and $\mathrm{P}$ by colorimetry. To determine $\mathrm{N}$ concentrations, samples were mineralized with sulfuric acid according to the semi-micro Kjeldahl method.

Obtained data underwent analysis of variance and regression using the Assistat software (Silva, 2015) Best fit linear, quadratic, logarithmic, and exponential models were chosen using regression coefficient and biological logic. 


\section{Results and Discussion}

No effect of crop density on first pod height in both cultivars and both growing seasons was observed (Figure 1). Likewise, Melhorança and Joba (1991) did not observe a significant effect of crop density on first pod height. However, Alcântara et al. (1991) obtained the highest first pod at the highest crop density. Plants with a high first pod, less lodged, and erect facilitate manual and mechanized harvest and other crop management practices (Mendes et al., 2009).
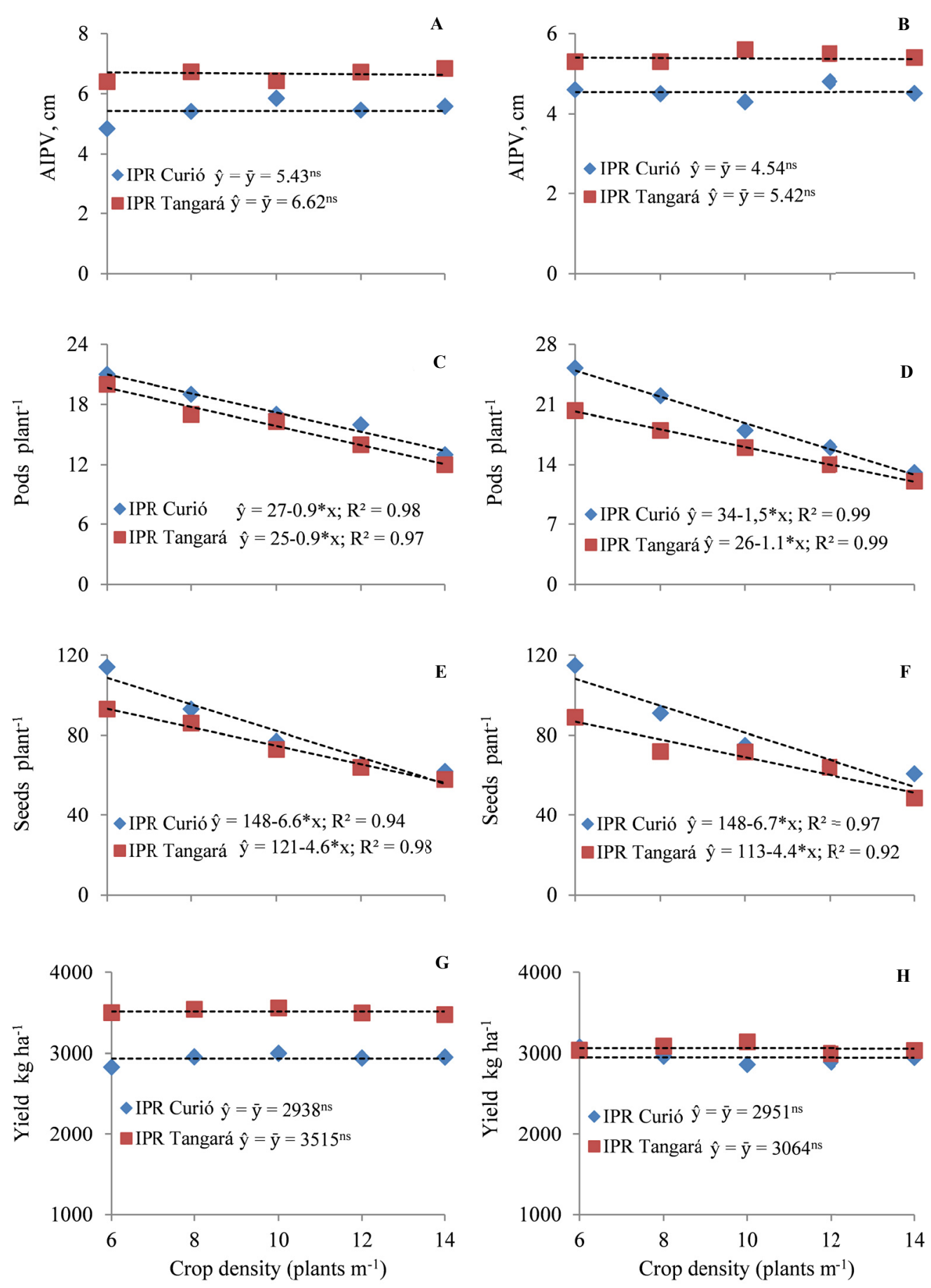

Figure 1. First pod height (A and B), pods per plant (C and D), seeds per plant (E and $F$ ), and seed yield ( $G$ and H) of two bean cultivars ('IPR Curió' and 'IPR Tangará') as a function of crop density in dry season (A, C, E, and $\mathrm{G})$ and wet season $(\mathrm{B}, \mathrm{D}, \mathrm{F}$, and $\mathrm{H}){ }^{\mathrm{ns}}$ and $*=$ not significant and significant at $5 \%$ probability by the $t$-test, respectively 
The number of pods per plant and the number of seeds per plant decreased linearly with increasing crop density for both cultivars and seasons (Figures $1 \mathrm{C}-1 \mathrm{~F}$ ). With crop density up from 8 to 14 plants $\mathrm{m}^{-1}$, the number of pods per plant for 'IPR Curió' was down $38 \%$ in the wet and $48 \%$ in the dry season, while for 'IPR Tangará' the reduction was $40 \%$ in both seasons. The same behavior was observed for the number of seeds per plant, which on average was down $46 \%$ for 'IPR Curió' and $41 \%$ for 'IPR Tangará' in both seasons, a trend already demonstrated by Agudelo et al. (1972) as a normal response of the species to high crop density.

Higher crop density leads to greater intraspecific competition, which reduces the number of pods per plant and the number of seeds per plant probably due to flower abortion and reduction (Távora et al., 2001; Lopes et al., 2011). Bezerra et al. (2010) found that an increased population density from 5 to 15 plants $\mathrm{m}^{-1}$ reduced the number of pods per plant by $63 \%$ and $69 \%$, respectively.

Seed yield was not significantly affected by seasons or crop densities (Figures $1 \mathrm{G}$ and $1 \mathrm{H}$ ). The average yield for 'IPR Curió' was $2944 \mathrm{~kg} \mathrm{ha}^{-1}$ and for 'IPR Tangará' $3289 \mathrm{~kg} \mathrm{ha}^{-1}$. Almeida \& Sangoi (1994) found that seed yield of 'Carioca' cultivar (indeterminate growth) decreased when crop density increased from 10 to 15 plants $\mathrm{m}^{\text {' }}$ ', but 'BR-6' (indeterminate growth) increased seed yield at the highest crop density. Bezerra et al. (2008) obtained $13.2 \%$ higher average yield $\left(1,836 \mathrm{~kg} \mathrm{ha}^{-1}\right)$ at 15 plants $\mathrm{m}^{-1}$ than 5 plants $\mathrm{m}^{-1}$.

Studying 'IPR Tangará' and different density arrangements, Souza et al. (2014) found that a population increase from 90 to 250 thousand plants per hectare reduced the number of pods per plant but did not affect seed yield. We therefore infer that under a small crop density on an experimental plot bean compensatory growth affects components of seed yield, as described by Adams (1967), Fernandes et al. (1989), and Ribeiro et al. (2004). Consequently, crop compensatory growth, if available, may help reduce production costs by using fewer seeds for planting.

Moura et al. (2012) stated that bean yield is related to the population of plants because the spatial arrangement affects the efficiency of solar radiation absorption. Santos et al. (2014b) found increased seed yield up to 15 plants $\mathrm{m}^{-1}$, and reduced seed yield from that point on. In this work, however, seed yield was similar at different plant densities, thus evidencing crop compensatory growth in both seasons. Therefore, planting density for both studied cultivars does not expressively interfere with components of yield.

No significant differences in leaf macronutrient levels were observed with respect to crop density in both seasons (Figures 2 and 3). What may have led to this result is the fact that the experiment was carried out under the no-till system (NTS) on a highly fertile soil, which was able to evenly provide nutrients to plants despite higher crop density. Straw accumulation on the soil under NTS favors nutrient recycling, soil aggregation, water storage, and soil organic matter maintenance, with positive effects on fertility (Boer et al., 2007; Crusciol \& Soratto, 2010).

Cultivars 'Pérola' and 'IAC Alvorada' under high levels of fertilization presented similar uptake and export of nutrients (Soratto et al., 2013). This means that in well-fertilized soils nutrient levels found in bean plants are usually equal, indicating that the level of soil fertility has a stronger impact on this trait than crop density. Among evaluated macronutrients, nitrogen and phosphorus levels were the highest, corroborating data found by Carvalho et al. (2014), and Perez et al. (2013). Common bean genotypes with higher biomass yield has, in general, higher nutrient uptake, mainly, $\mathrm{N}$ and $\mathrm{P}$ (Westermann et al., 2011). 

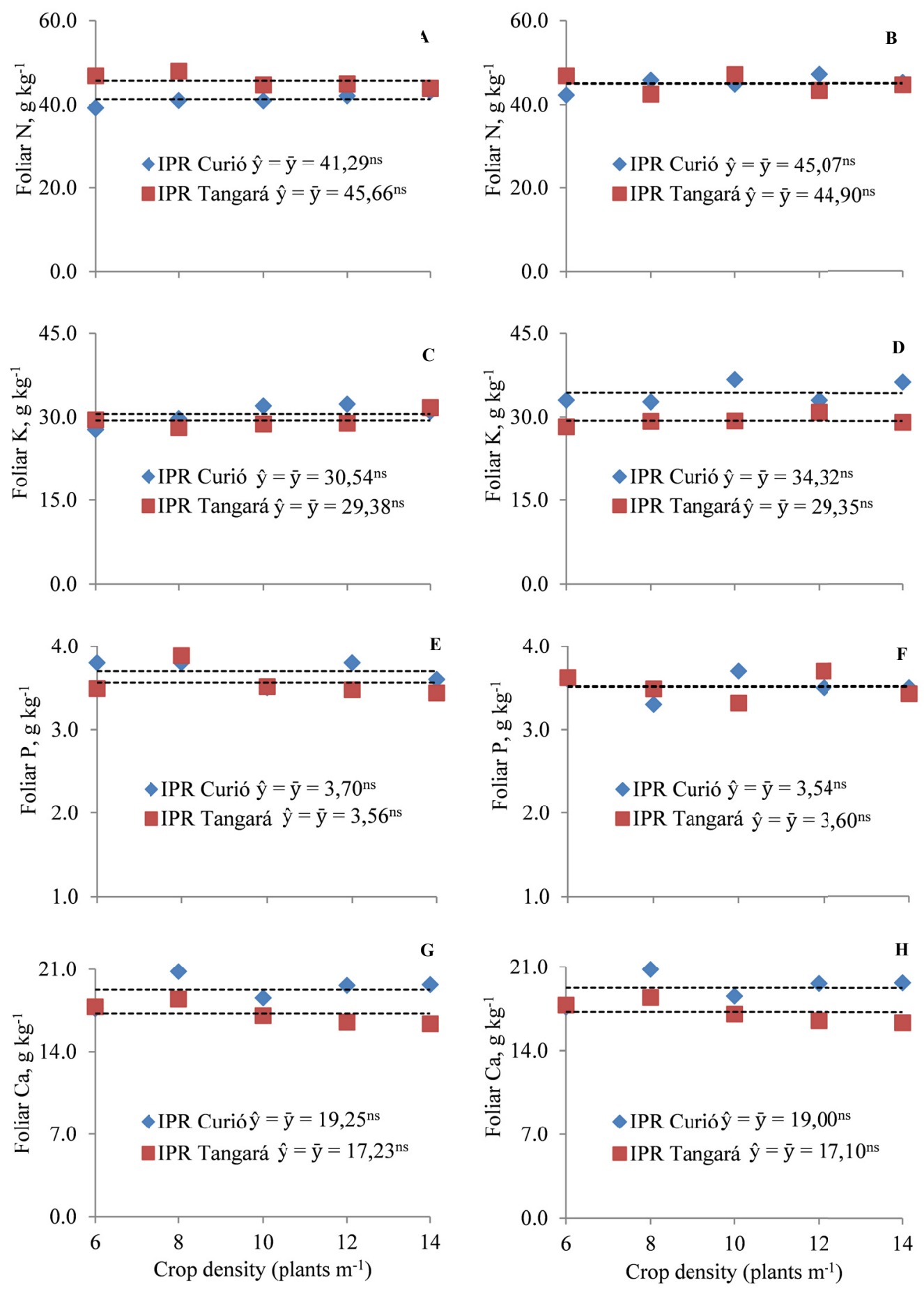

Figure 2. Levels of nitrogen (A and B), potassium (C and D), phosphorus (E and F), and calcium $(\mathrm{G}$ and $\mathrm{H})$ in leaves of two bean cultivars ('IPR Curió' and 'IPR Tangará') as a function of crop density in dry season (A, C, E, and $\mathrm{G}$ ) and wet season $(\mathrm{B}, \mathrm{D}, \mathrm{F}$, and $\mathrm{H}){ }^{\mathrm{n}}{ }^{\mathrm{n}}=$ not significant at $5 \%$ probability by the $t$-test 

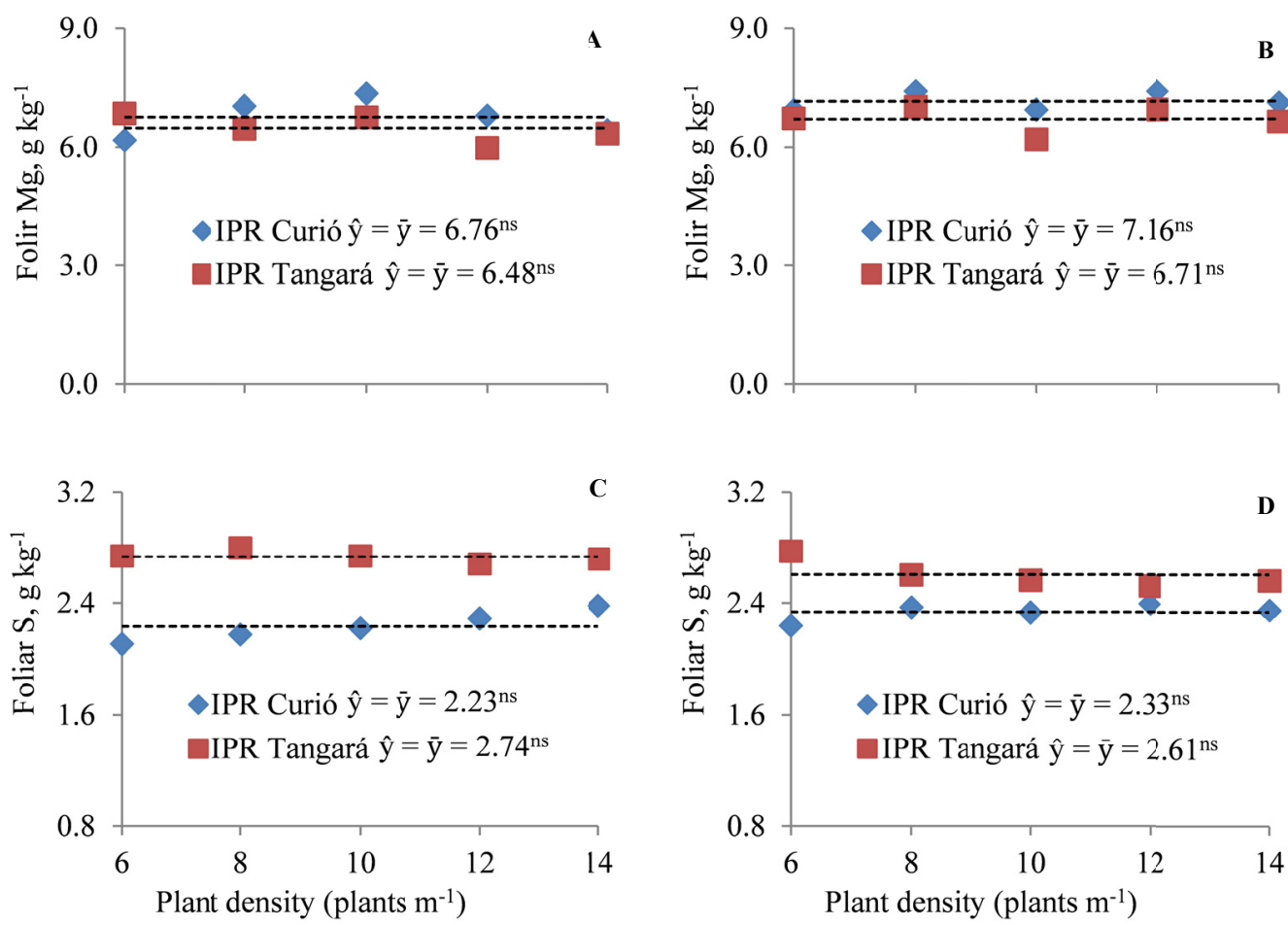

Figure 3. Levels of magnesium (A and B) and sulfur (C and D) in leaves of two bean cultivars ('IPR Curió' and 'IPR Tangará') as a function of crop density in wet ( $\mathrm{A}$ and $\mathrm{C}$ ) and dry season $(\mathrm{B}$ and $\mathrm{D}) .{ }^{\mathrm{ns}}=$ not significant at $5 \%$ probability by the t-test

Except $\mathrm{N}$ and $\mathrm{Mg}$ levels, which were slightly above the optimal, other macronutrient levels obtained in this study were mainly within the reference levels recommended by the Manual of Fertilization and Liming for the State of Parana, Brazil, which are: $30-40 \mathrm{~g} \mathrm{~kg}^{-1} \mathrm{~N} ; 28-35 \mathrm{~g} \mathrm{~kg}^{-1} \mathrm{~K}$; 3.5-8 $\mathrm{g} \mathrm{kg}^{-1} \mathrm{P}$; $15-30 \mathrm{~g} \mathrm{~kg}^{-1} \mathrm{Ca}$; 3-6 g kg $\mathrm{Mg}$; and 2-5 $\mathrm{g} \mathrm{kg}^{-1} \mathrm{~S}$ (SBCS/NEPAR, 2017).

It is expected that changes in crop density affect nutrient uptake due to modifications in the plant-water relations, leading to lower uptake of nutrients from the soil. However, as observed in this study, other factors such as nutrient availability and compensatory growth likely promoted uptake levels similar to those of macronutrients in plants.

\section{Conclusions}

Higher crop density per linear meter decreased the number of seeds and pods per plant but did not change macronutrient uptake, first pod height, and bean yield in 'IPR Tangará' and 'IPR Curió' in dry and wet season.

\section{References}

Adams, M. W. (1967). Basis of yield component compensation in crop plants with special reference to the field bean, Phaseolus vulgaris L. Crop Science, 7, 505-510. http://doi.org/10.2135/cropsci1967.0011183X00 0700050030x

Agudelo, D. O., Hernandez, L. A., \& Bastidas, R. G. (1972). Efecto de la densidade de plobacion em El rendimiento y otras características agronômicas Del frijol (Phaseolus vulgaris L.). de crescimento voluble y arbustivo. Acta Agronomica, 22, 39-50. https://doi.org/10.15446/acag

Alcântara, J. D. P., Ramalho, M. A. P., Abreu, A. de F. B., \& Santos, J. B. (1991). Avaliação de cultivares de feijão (Phaseolus vulgaris L.) em diferentes densidades de semeadura e condições de ambiente. Ciência e Prática, 15, 375-384. https://doi.org/10.1590/S0006-87052009000200007

Almeida, M. L., \& Sangoi, L. (1994). Manejo de cultivares de feijão de diferentes hábitos de crescimento no planalto catarinense. I. Rendimento de grãos. Ciência Rural, 24, 513-517. https://doi.org/10.1590/ S0103-84781994000300011 
Bezerra, A. A. C., Távora, F. J. A. F., Freire Filho, F. R., \& Ribeiro, V. Q. (2010). Características de dossel e de rendimento em feijão-caupi ereto em diferentes densidades populacionais. Pesquisa Agropecuária Brasileira, 44, 1239-1245. https://doi.org/10.1590/S0100-204X2009001000005

Boer, C. A., Assis, R. L., Silva, G. P., Braz, A. J. B. P., Barroso, A. L. L., Cargnelutti Filho, A., \& Pires, F. R. (2007). Ciclagem de nutrientes por plantas de cobertura na entressafra em um solo de cerrado. Pesquisa Agropecuária Brasileira, 42, 1269-1276. https://doi.org/10.1590/S0100-204X2007000900008

Carvalho, J. J., Saad, J. C. C., Bastos, A. V. S., Naves S. S., Soares, F. A. L., \& Vidal, V. M. (2014). Teor e acúmulo de nutrientes em grãos de feijão comum em semeadura direta, sob déficit hídrico. Irriga, 1, 104-117. https://doi.org/10.12702/ii.inovagri.2014-a138

Comissão Técnica Sul-Brasileira de Feijão. (2012). Informações técnicas para o cultivo de feijão na Região Sul brasileira (2nd ed., p. 157). Florianópolis: Epagri. Retrieved from http://www.epagri.sc.gov.br/wp-content/ uploads/2013/10/informacoes_tecnicas_cultivo_feijao.pdf

CONAB (Companhia Nacional De Abastecimento). (2017). Séries Históricas de Área Plantada, Produtividade e Produção, Relativas às Safras 1976/77 a 2015/16 de Grãos. Retrieved from http://www.conab.gov.br/ conteudos.php?a=1252\&Pagina_objcmsconteudos=2\#A_objcmsconteudos

Crusciol, C. A. C., \& Soratto, R. P. (2010). Sistemas de produção e eficiência agronômica de fertilizantes. In L. I. Prochnow, V. Casarin, \& S. R. Stipp (Eds.), Boas práticas para uso eficiente de fertilizantes (Vol. 1, pp. 229-275). Piracicaba, IPNI.

Fernandes, M. I. P. F., Ramalho, M. A. P., \& Lima, P. C. (1989). Comparação de métodos de correção de estande em feijão. Pesquisa Agropecuária Brasileira, 24, 997-1002.

Lima, R. T., Nascimento, V., \& Andreani Junior, R. (2016). Densidade de plantas e fontes de nitrogênio no cultivo de feijoeiro. Brazilian Journal of Biosystems Engineering, 10, 327-338.

Lopes, F. das C. L. (2011). Estudo de densidade de semeadura e espaçamento de linhas sobre o rendimento do feijão vigna unguiculata em condição do Agreste pernambucano (Unpublished master's thesis, Universidade Federal do Ceará, Ceará, Brazil).

Masa, M., Tana, T., \& Ahmed, A. (2017). Effect of plant spacing on yield and yield related traits of common bean (Phaseolus vulgaris L.) varieties at Areka, Southern Ethiopia. Plant Biology \& Soil Health, 4, 1-13. https://doi.org/10.13188/2331-8996.1000020

Melhorança, A. L., \& Joba, I. (1991). Efeito do espaçamento entrelinhas sobre o desenvolvimento e produção do feijão (Phaseolus vulgaris L.). Dourados: Empresa Brasileira de Pesquisa Agropecuária.

Mendes, F. M., Ramalho, M. G. P., \& Abreu, A. F. B. (2009). Índice de seleção para escolha de populações segregantes em feijoeiro-comum. Pesquisa Agropecuária Brasileira, 44, 1312-1318. https://doi.org/ $10.1590 / \mathrm{S} 0100-204 \mathrm{X} 2009001000015$

Morgade, L., \& Willey, R. (2003). Effect of plant population and nitrogen fertilizer on yield and efficiency of maize/bean intercropping. Pesquisa Agropecuária Brasileira, 3, 1257-1264. https://doi.org/10.1590/ S0100-204X2003001100002

Moura, J. Z., Pádua, L. E. M., Moura, S. G., Torres, J. S., \& Silva, P. R. R. (2012). Escala de desenvolvimento fenológico e exigência térmica associada a graus-dia do feijão-caupi. Revista Caatinga, 25, 66-71.

Oliveira, S. A. (2004). Análise foliar. In D. M. G. Sousa, \& E. Lobato (Ed.), Cerrado: Correção do solo e adubação (pp. 245-256). Brasília: Embrapa Informação Tecnológica.

Perez, A. A. G., Soratto, R. P., Manzatto, N. P., \& Souza, E. de F. C. de. (2013). Extração e exportação de nutrientes pelo feijoeiro adubado com nitrogênio, em diferentes tempos de implantação do sistema plantio direto. Revista Brasileira de Ciência do Solo, 37, 1276-1287. https://doi.org/10.1590/S0100-0683201300 0500017

Ribeiro, N. D., Cargnelutti Filho, A., Jost, E., Poersch, N. L., \& Trentin, M. (2004). Alterações em caracteres agromorfológicos em função da densidade de plantas em cultivares de feijão. Revista Brasileira de Agrociências, 10, 167-173.

Santos, H. G., Jacomine, P. K. T., Anjos, L. H. C., Oliveira, V. A., Lubreras, J. F., Coelho, M. R., ... Oliveira, J. B. (2014a). Sistema brasileira de classificação de solos (4th ed., p. 376). Brasília: Embrapa. 
Santos, M. G. P., Carvalho, A. J., David, A. M. S. S., Amaro, H. T. R., Souza, V. B., \& Carneiro, J. E. S. (2014b). Densidades de semeadura e safras de cultivo no desempenho produtivo de cultivares de feijoeiro-comum. Semina: Ciências Agrárias, 35, 2309-2324. https://doi.org/10.5433/1679-0359.2014v35n5p2309

SCBS/NEPAR (Sociedade Brasileira de Ciência do Solo/Núcleo Estadual Paraná). (2017). Manual de adubação e calagem para o Estado do Paraná. Curitiba, PR: Sociedade Brasileira de Ciência do solo.

Silva, F. A. S. (2015). Assistat (Versão 7.6 Beta). Universidade Federal de Campina Grande: Paraíba.

Silva, J. G., \& Silva, C. C. (2005). Plantio e tratos culturais. In T. Cubucci, \& M. Biava (Eds.), Cultivo do Feijão Irrigado na Região Noroeste de Minas Gerais. Santo Antônio de Goiás-GO: Embrapa Arroz e Feijão.

Soil Survey Staff. (2010). Keys to soil taxonomy (11th ed., p. 338). Washington, DC: USDA/NRCS.

Soratto, R. O., Catuchi, T. A., Souza, E. F. C., \& Garcia, J. L. N. (2017). Plant density and nitrogen fertilization on common bean nutrition and yield. Caatinga, 30, 670-678. https://doi.org/10.1590/1983-21252017 v30n315rc

Soratto, R. P., Fernandes, A. N., Sanots, L. A., \& Job, A. L. G. (2013). Nutrient extraction and exportation by common bean cultivars under different fertilization levels: I-macronutrients. Revista Brasileira de Ciência do Solo, 37, 1027-1042. https://doi.org/10.1590/S0100-06832013000400020

Souza, A. B., Oliveira, D. P., Silva, C. A., \& Andrade, M. J. B. (2014). Populações de plantas e doses de nitrogênio para o feijoeiro em sistema convencional. Bioscience Journal, 30, 998-1006.

Távora, F. J. A. F., Nogueira, S. L., \& Pinho, J. L. N. (2001). Arranjo e população de plantas em cultivares de feijão-de-corda com diferentes características de copa. Ciência Agronômica, 32, 69-77.

Tuarira, M., \& Moses, M. (2014). Effects of plant density and planting arrangement in green bean seed production, J. Glob. Innov. Agric. Soc. Sci., 2, 152-157. https://doi.org/10.17957/JGIASS/2.4.516

Vieira, C., Borém, A., Ramalho, M. A. P., \& Carneiro, J. E. de S. (2005). Melhoramento do feijão. In A. Borém (Ed.), Melhoramento de espécies cultivadas (2nd ed.). Viçosa: UFV. https://doi.org/10.1094/PDIS-943-0361

Vieira, R. F., Paula Júnior, T. J., Carneiro, J. E. S., \& Queiroz, T. F. N. (2010). White mold management in common bean by increasing within row distance between plants. Plant Disease, 94, 361-367.

Westermann, D., Terán, H., Muñoz-Perea, C., \& Singh, S. (2011). Plant and seed nutrient uptake in common bean in seven organic and conventional production systems. Canadian Journal of Plant Science, 91(6), 1089-1099. https://doi.org/10.4141/cjps10114

\section{Copyrights}

Copyright for this article is retained by the author(s), with first publication rights granted to the journal.

This is an open-access article distributed under the terms and conditions of the Creative Commons Attribution license (http://creativecommons.org/licenses/by/4.0/). 